\title{
Numerical Simulation of a Road Cut Slope along SH-72, Mahableshwar, Maharashtra, India
}

\author{
Ashutosh Kainthola ${ }^{1^{*}}$, Dhananjai Verma ${ }^{2}, \mathrm{~T}$ N Singh ${ }^{3}$ \\ ${ }^{1}$ KainGeotech Pvt. Ltd., Dehradun-248001, India \\ ${ }^{2}$ Geological Survey of India, Gandhinagar, 382010, India \\ ${ }^{3}$ Department of Earth Sciences, Indian Institute of Technology Bombay, 400076, India \\ Email: ashukainthola@gmail.com
}

\begin{abstract}
Hill stations which are favoured tourist destinations are mostly accessible by road excavated on the hill slopes. These roads cut slopes pose a grave threat to life and local economics in case of a slope failure. Proper study is called for to mitigate this danger of these slope failures which are especially rampant during the rainy season. In the present study a road cut slope along SH-72 near Mahableshwar, Maharashtra, India, has been numerically simulated using finite element and finite difference techniques to appraise their stability under dry and saturated conditions.
\end{abstract}

Keywords: Slope stability, FOS, numerical analysis, mahableshwar.

\section{Introduction}

The hill stations are favored tourist destinations around the world and a major source of revenues. Mahabaleshwar is one of the important tourist attractions in India due to its peculiar climate and aesthetic locales. The approach to these hilly areas is mostly roads excavated on the hill slopes. These cut slopes pose serious problem resulted from heavy rain fall and disturbance due to construction of civil structures viz. road widening. Failures of these rock slopes, both man-made and natural, include rock falls, overall slope instability and landslides. Landslides in hilly regions are quite difficult to understand. The problem of landslide increases day by day and is robustly influenced by development of various works like road widening, hydropower development and many more infrastructural projects.

Slope instability or landslides are the same natural denudational and degradational processes, unless they threaten human life. Their interference with ongoing human activities in the terrain marks a landslide hazard which requires a thorough analysis for their stability assessment and required mitigation. According to Varnes's (1984) hazard can be illustrated as:

$$
\mathrm{Rs}=\mathrm{H}^{*} \mathrm{~V}
$$

where, Natural hazard $(\mathrm{H})$ is the probability of occurrence of a potentially damaging Phenomenon within a specified period of time and within a given area (Figure 1). Vulnerability (V) is the degree of loss of a given element or set of elements at risk resulting from the occurrence of a natural phenomenon of a given magnitude. Scale is 0 (no change) to 1 (total loss) and Specific risk (Rs) is the expected degree of loss due to a particular natural phenomenon. It may be expressed by the product of $\mathrm{H}$ and $\mathrm{V}$.

Numerical and analytical methods are the most important tools to study the slopes in order to mitigate them effectively (Bishop 1955, Janbu 1957, Sarma 1975, Spencer 1967, Griffiths and Lane, 1999, Verma et al, 2011: Verma et al, 2013a: : Verma et al, 2013b: : Verma et al, 2014: ). Analytical methods use simple slice-like techniques based on the limit equilibrium method, but this tool has limitations and is not very useful for complex rock mass modeling. In the limit equilibrium method, the mode of failure is presumed and then the factor of safety (FOS) gets calculated. Failure occurs when the driving forces such as gravity, water pressure etc. become greater than the resisting forces. i.e. friction, cohesion, etc.

Numerical methods such as the finite element method (FEM), the finite difference method (FDM), the boundary element method (BEM), and the distinct element method (DEM) are becoming increasingly popular for slope stability analysis in situations where the failure mechanism is not controlled completely by discrete geological structures (Monjezi and Singh 2000, Sarkar et al. 2010, Singh and Verma, 2007). 
The two important numerical tools consist of finite element analysis (FEA) and the finite difference analysis (FDA). The finite element code is a continuum model which can be used for analysis of complex geometries, stress modelling and material behaviour. Here, the rock mass is considered as a continuum, and is divided into a finite number of elements with intersecting nodes. In the FEA, the structural system is modelled by a set of appropriate finite elements interconnected at points called nodes. A major advantage of the finite element- SSR method is that it does not entail any earlier assumptions on the nature of failure mechanisms. The Shear Strength Reduction technique in the finite element method involves successive reduction (by some factors) in the shear strengths of the slope material until it fails, which is indicated by the non-convergence to a solution of the finite element model (Griffiths and Lane, 1999: Kainthola et al, 2011: Kainthola et al, 2011b: Kainthola et al, 2011c: Kainthola et al, 2013a: Kainthola et al, 2013b: Monjezi and Singh 2000). Finite difference analysis (FEA) is another robust for geotechnical calculations (Cundall, 1976: Sarkar et al, 2010: Sarkar \& singh, 2011). In FEA, every derivative in the set of governing equations is replaced directly by an algebraic expression written in terms of the stress and displacement at discrete points in space.

The present study deals with the numerical simulation of a $20 \mathrm{~m}$ high red bole road cut slope near Mahablehswar, Maharashtra, India, using FEA and FDA techniques under dry and saturated conditions for the assessment of their stability.

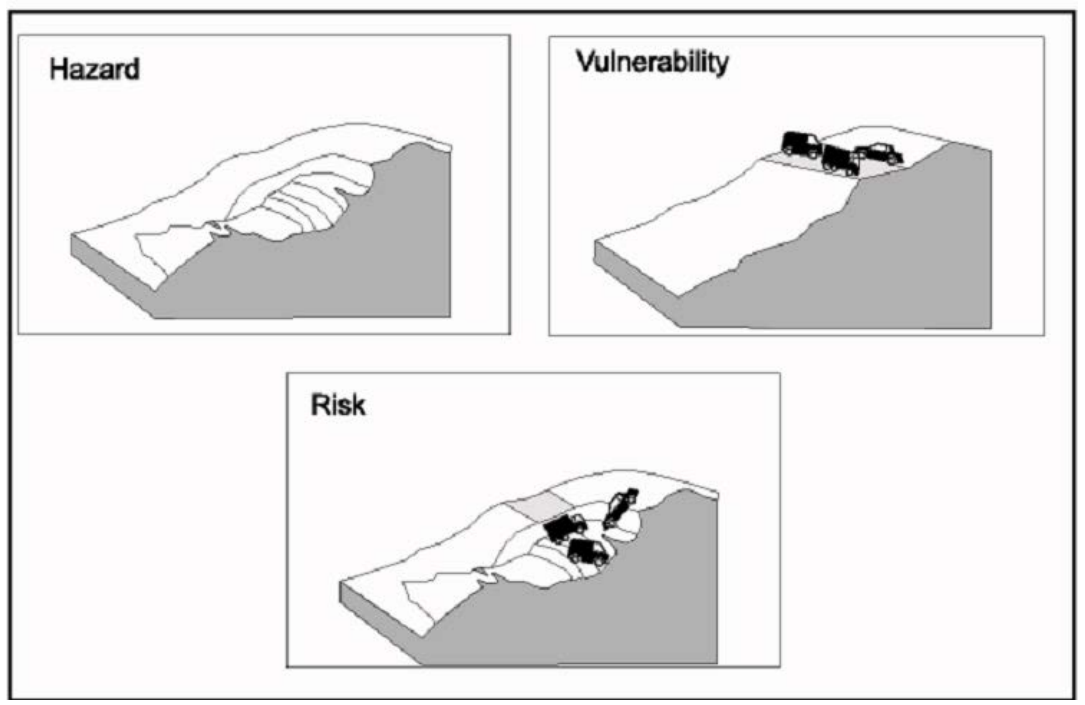

Figure 1. Graphical representation of hazard, vulnerability and risk (Varnes, 1984).

\section{Study Area and Geology}

The study area comprises a $20 \mathrm{~m}$ high road cut slope along long hilly road cut slope from Poladpur to Mahabaleshwar along the state highway- 72 in the Satara district, Maharashtra, India (Figure 2). The road is stopped during monsoon period from July to September to avoid accidents and loss of economy. The cut slopes in this area are susceptible to failure due to complexity in their geological setup i.e. composition and flow characteristics of basalt in the mountains in addition to the presence of weak Red bole layers coupled with heavy rainfall during the monsoon. The slope consists of highly weathered basalt rocks intercalated with bed bole layers which are clayey or earthy reddened layers intercalated between basalt flows considered to be paleosols (Sayyed \& Hundekar, 2006). The Bole beds occur at the flow contacts of Deccan basalts and are often marked by prominent red to chocolate brown, earthy brown, green, purple gray colors and are composed of an admixture of clay, silt and sand sized grains (Inamdar and Darshan Kumar, 1994). The red bole layers considerably loose their strength and behave like a soil when they come in contact with water. The exposure of the red bole layers weakens the slope mass as a whole due to its high incompetence due to saturation. 


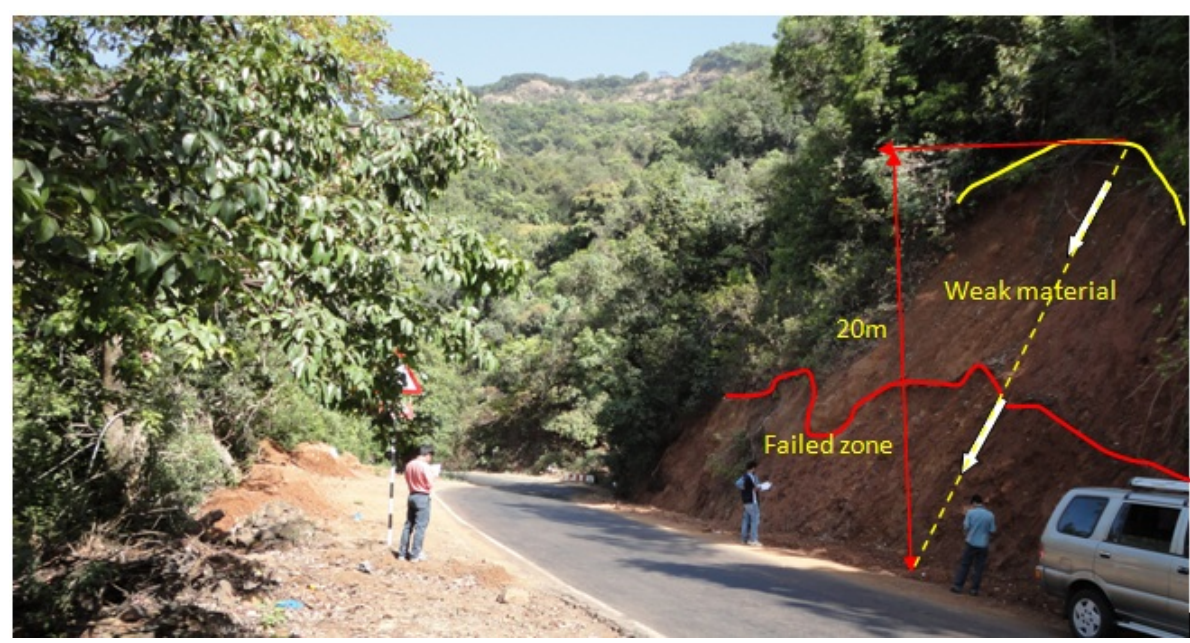

Figure 2. The cut slope along the road cut on SH-72, near Mahabaleshwar, India.

\subsection{Laboratory Experiment}

The representative rock samples and red bole samples collected from the field were brought to the laboratory for measurement of their geotechnical properties. The samples were tested for their cohesion, angle of internal friction, youngs modulus, poisons ration and unit weight under dry as well as saturated conditions (Table 1). These properties were used as input parameters for the numerical simulation to evaluate the slopes stability.

Table 1. The geotechnical properties of the slope mass.

\begin{tabular}{|c|c|c|c|c|c|c|c|c|c|c|}
\hline \multirow[t]{2}{*}{$\begin{array}{l}\text { Rock } \\
\text { Type }\end{array}$} & \multicolumn{2}{|c|}{$\begin{array}{l}\text { Mean Unit } \\
\text { weight } \\
\left(\mathrm{MN} / \mathrm{m}^{3}\right) \\
\end{array}$} & \multicolumn{2}{|c|}{$\begin{array}{l}\text { Mean Cohesion } \\
\quad(\mathrm{MPa})\end{array}$} & \multicolumn{2}{|c|}{$\begin{array}{c}\text { Mean Angle of internal } \\
\text { friction } \\
\left({ }^{0}\right)\end{array}$} & \multicolumn{2}{|c|}{$\begin{array}{l}\text { Youngs } \\
\text { modulus } \\
(\mathrm{GPa})\end{array}$} & \multicolumn{2}{|c|}{ Poissons ratio } \\
\hline & Dry & Saturated & Dry & Saturated & Dry & Saturated & Dry & Saturated & Dry & Saturated \\
\hline $\begin{array}{c}\text { Weathered } \\
\text { Basalt }\end{array}$ & 0.026 & 0.277 & 1.21 & 0.9 & 29 & 27 & 1.3 & 1.24 & 0.26 & 0.264 \\
\hline Red bole & 0.022 & 0.251 & 0.09 & 0.065 & 23 & 19 & 0.8 & 0.62 & 0.27 & 0.277 \\
\hline
\end{tabular}

\section{Numerical Simulation}

The stability analysis was carried out in both finite element and finite difference codes. A model of $20 \mathrm{~m}$ high slopes with an inclination of $70^{\circ}$ generated in the simulation tool. The simulation was carried out for both dry and saturated conditions.

For the FEA a two- dimensional four noded quadrilateral mesh was generated for better discretization of the cut slope (Cook et al. 1974). In FDA fine rectangular grids were generated for the analysis. The physico-mechanical properties of the slope forming material were used as the input simulation. The slope geometry and input properties used in the FEA and FDA were same. 


\section{Result and Discussions}

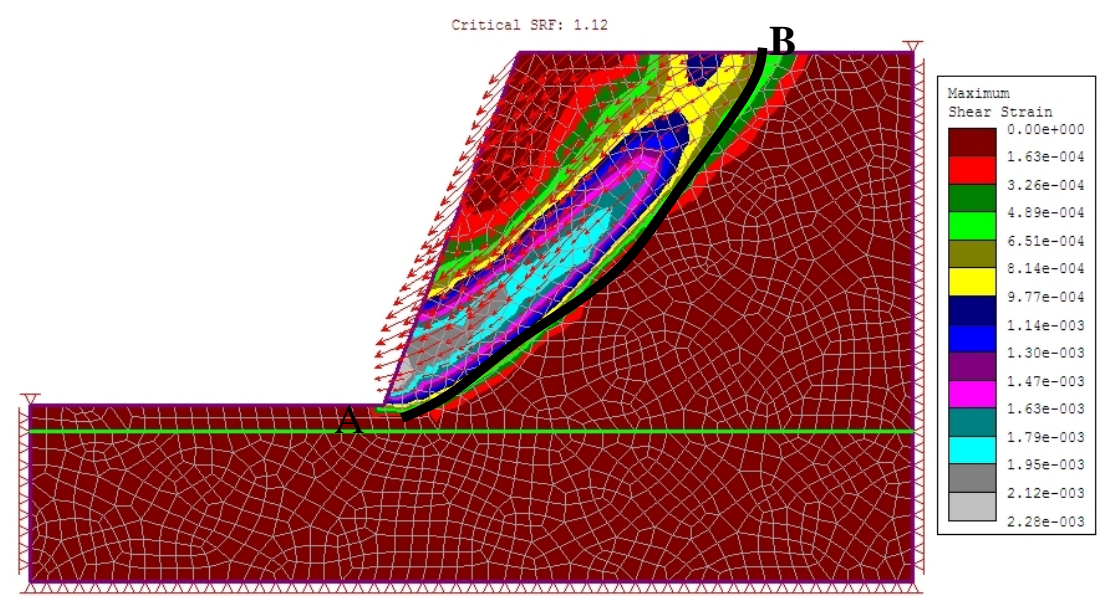

Figure 3. The cut finite element model for the cut slope (dry condition).

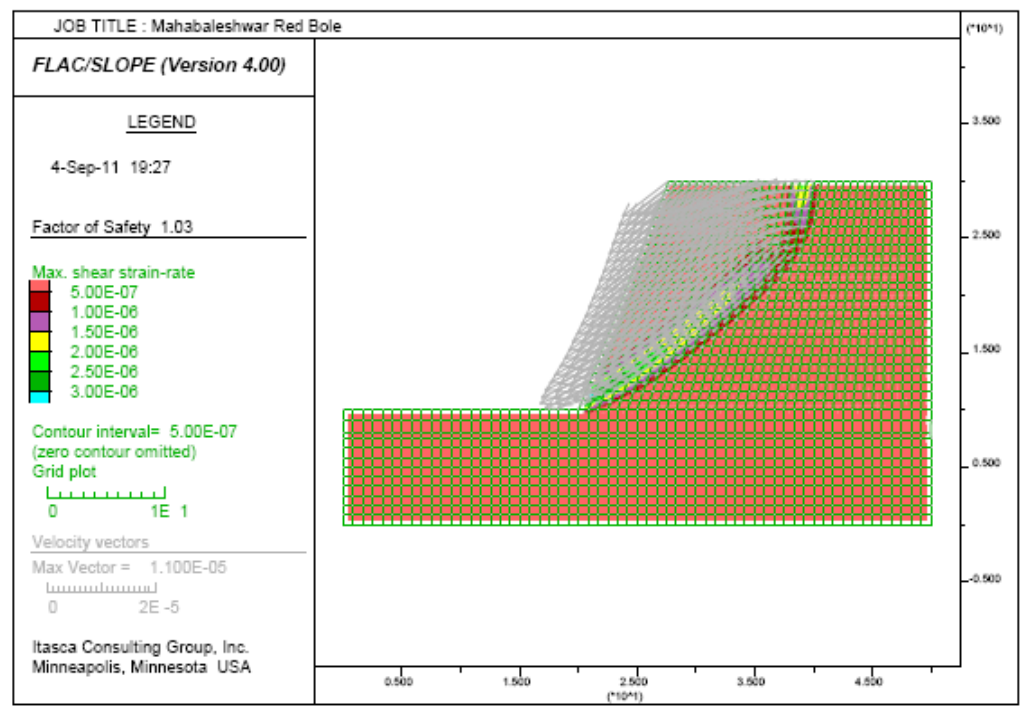

Figure 4. The finite difference model for the cut slope (dry condition).

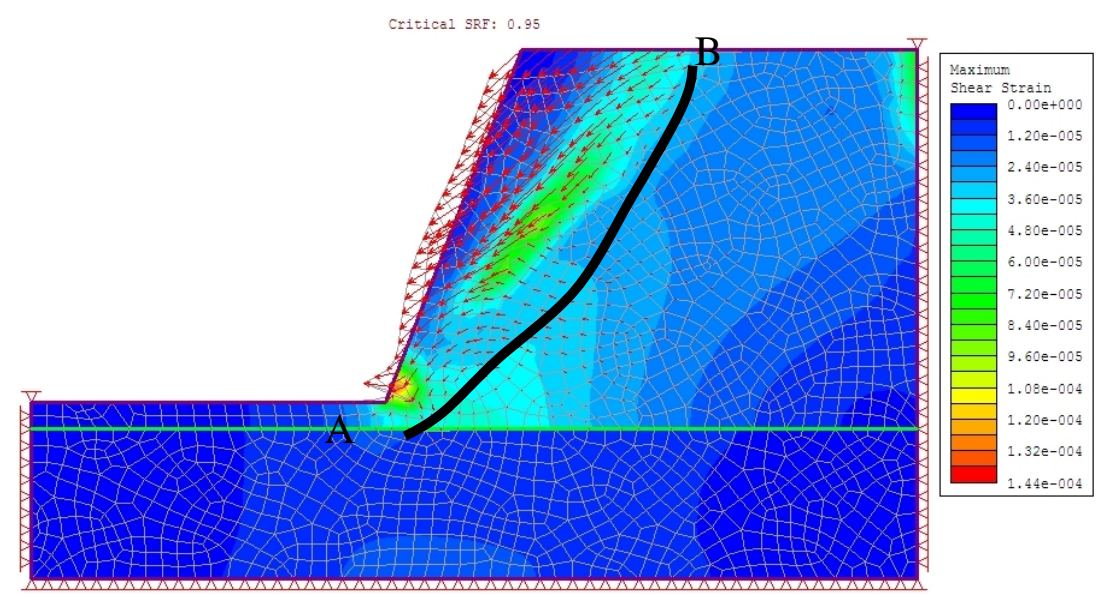

Figure 5. The finite element model for the cut slope (saturated condition). 


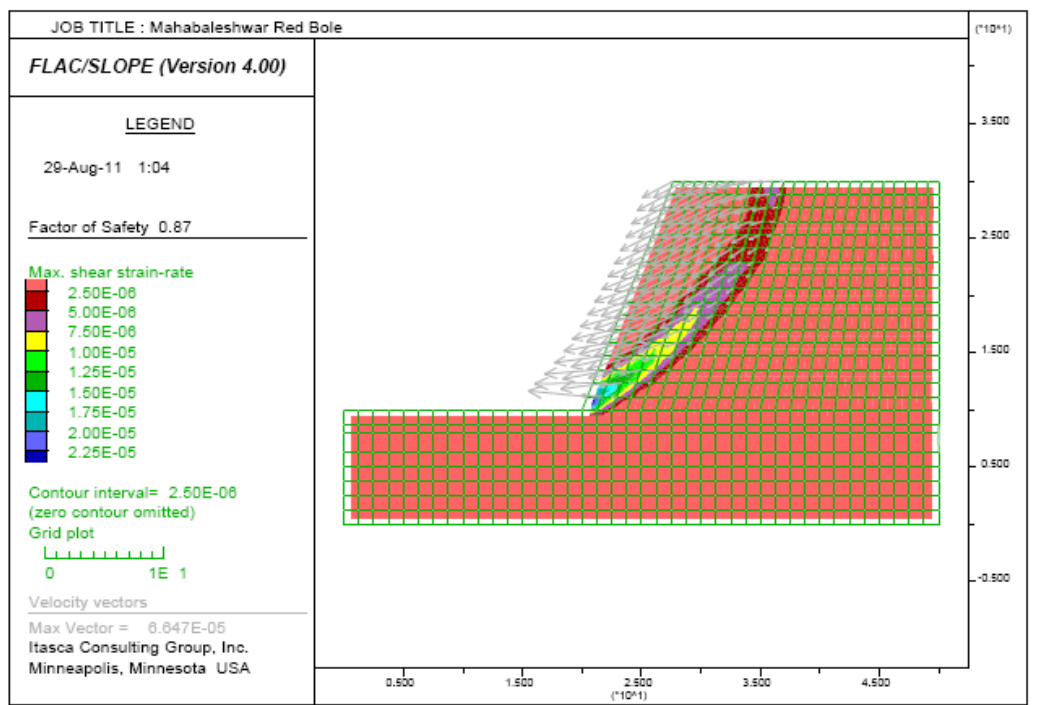

Figure 6. The finite difference model for the cut slope (saturated condition).

A factor of safety (FOS) of 1.12 was yielded in FEA for the dry condition in while in FDA the factor of safety was almost unity. The calculated safety factors for both the analysis render them a critical stability (Figure $3 \& 4$ ).

The factor of safety diminished by $15 \%$ in both the FEA and FDA to 0.95 and 0.87 respectively (Figure 5 \& 6).

In the finite difference analysis the shear strain rate increased from $3 \times 10^{-6}$ under the dry condition to $2.25 \times 10^{-5}$ under the saturated condition. The higher strain rate is due to the lower strength and higher deformation of the slope forming material.

There was a reduction in effective shear stress generated along the probable failure plane when the slope was simulated for wet condition (Figure 7). The maximum shear stress was generated along the toe of the slope which gradually dissipated as the failure plane reached the top of the slope, but it clearly indicates that the saturated conditions accelerates the failure at faster rate in the initial state. Figure 7, demonstrates the triggering effect of water in the slope failure.

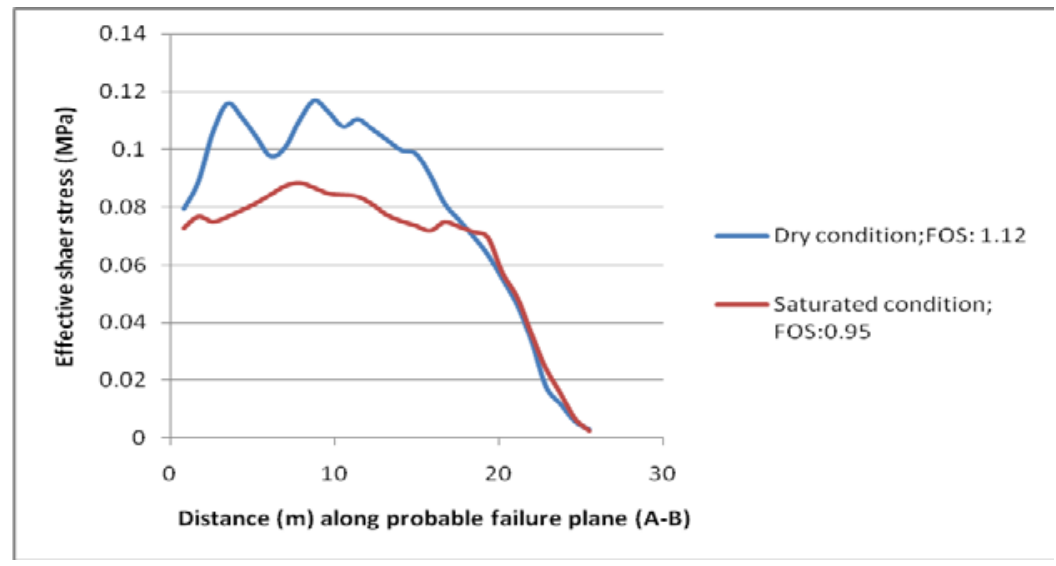

Figure 7. The variation of effective shear stress along the probable failure plane A-B for both conditions.

\section{Conclusions}

The present study deals with the finite element and finite difference analysis of a road cut slope under both dry and saturated conditions. The cut slope composed of weathered Basalt and Red bole was found 
to be in a critical state of safety in the dry condition, while it failed when simulated for saturated condition. The numerical study conforms to the field observations. A $15 \%$ reduction in FOS was found from dry to saturated condition in both FEA and FDA. The cut slope needs to be strengthened at the toe level to improve its shear strength in order to prevent its collapse.

Acknowledgement. The authors would like to thank DST, New Delhi, India, for their generous funding of the research project.

\section{References}

1. Beane, J.E., Turner, C.A., Hooper, P.R, Subbarao, K.V., and Walsh, J.N. (1986). Stratigraphy, composition and form of Deccan Basalts, Western Basalts, Western Ghats, India, Bull. Volc., V. 48, pp. 61-83.

2. Bishop, A.W. (1955) The use of the slip circle in the stability analysis of slopes. Geotech. V. 1, pp. 17.

3. Cook, R.D., Malku, D. S., Plesha, M E. (1974) Concepts and Application of finite element analysis, Edn. 3, New York: Jhon Wiley \& Sons.

4. Cundall, P. (1976) Explicit Finite Difference Methods in Geomechanics in numerical Methods in Engineering. Proceedings of the EF Conference on Numerical Methods in Geomech. Blacksburg, Virginia, V. 1, pp. 132-150.

5. Frizzell, E.M. and Watts, C.F. (1988) Back analysis of plane and wedge rock slope failures using microcomputer programs. In Proceedings of the Society of Mining Engineers/ American Institute of Mining Engineers Annual Meeting, Phoenix, AZ.Symposium on Explorer for Rock Engineering, V. 5, pp. 97-106.

6. Griffiths, D.V. and Lane, P.A. (1999) Slope stability analysis by finite elements, Geotech. V. 49(3), pp. 387-403.

7. Inamdar, P.M., Darshan, K. (1994) On the origin of bole beds in Deccan Traps. Jour. Geol. Soc. Ind, V. 44, pp. 331-334.

8. Janbu, N. (1957) Earth pressure and bearing capacity by generalized procedure of slices. In Proc. Fourth Int. Conf. on Soil Mech. London, V. 2, pp. 207-212.

9. Kainthola, A., Verma, D., Gupte, S.S. and Singh, T.N. (2011). A Coal mine dump stability analysis - a case study, Int. J. of Geomaterial, V. 1, pp. 1-13.

10.Kainthola, A., Verma, D., T. N. Singh, (2011c), Computational Analysis for the Stability of Black Cotton Soil Bench in an Open Cast Coal Mine in Wardha Valley Coal Field, Maharashtra, India, Int. J. Econ. Env.Geol. 2(1):11-18

11. Kainthola, A., verma, D. „\& Singh, T. N. (2013). Probabilistic and Sensitivity Investigation for the Hill Slopes in Uttarakhand, Lesser Himalaya, India. American Journal of Numerical Analysis, 1(1), 8-14.

12.Kainthola, A., verma, D. ,Thareja, R., \& Singh, T. N. (2013). A Review on Numerical Slope Stability Analysis. International Journal of Science, Engineering and Technology Research, V. 2, (6), 1315-1320

13. Monjezi, M. and Singh, T.N. (2000), Slope instability in an open cast mine, coal international, V. 8, pp. 145-147. 14. Sayyed, M. R.G. and S.M. Hundekari (2006) Preliminary comparison of ancient bole beds and modern soils developed upon the Deccan volcanic basalts around Pune (India): Potential for palaeoenvironmental reconstruction, Quaternary International, V. 156-157, pp. 189-199.

15. Sarkar, K., Singh, T.N .and Verma, A. K. (2010) A numerical simulation of landslide-prone slope in Himalayan region - a case study, International Journal of Arabian Geosciences, DOI:10.1007/s12517-010-0148-8.

16. Sarkar K. and T.N.Singh (2011) Instability analysis of slope along NH-22 around Sainj area, HP, Ind. Lands., V. 4(1):09-12.

17. Sarma, S.K. (1975) Seismic stability of earth dams and embankments. Geotech. V. 25, pp. 743-761.

18. Singh, T.N. and Verma, A.K. (2007) Evaluating the slope instability of the Amiyan Slide. In Rock Mechanics Meeting Society's Challenges and Demands, E. Eberhardt, D. Stead and T. Morrison (Eds), pp. 993-998.

19. Spencer, E. (1967) A method of analysis of the stability of embankments assuming parallel interslice forces. Geotech. V. 17, pp. 11-26.

20. Varnes, D.J. (1984) Landslide hazard zonation: A review of principles and practice. IAEG Monograph, UNESCO, pp. 59.

21.Verma, D., Thareja, R., Kainthola, A. , \& Singh, T. N. (2011). Evaluation of Open Pit Mine Slope Stability Analysis. International Journal of Earth Sciences and Engineering, Vol. 04 (04), 590-600 
22.Verma, D., Kainthola, A. Thareja, R., \& Singh, T. N. (2013a). Stability Analysis of an Open Cut Slope in Wardha Valley Coal Field,Journal of the Geological Society of India, Vol 81(6) 804.

23. Verma D., Kainthola A., Gupte S. S., and Singh T. N. (2013b). A Finite Element Approach of Stability Analysis of Internal Dump Slope in Wardha Valley Coal Field, India, Maharashtra, American Journal of Mining and Metallurgy, Vol. 1(1), pp. 1-6

24.Verma, D., Kainthola, A., Singh, T. N. \&Thareja, R., (2014)Influence of water content on Geotechnical Properties of Deccan Basalt, Maharashtra, India, IRJGM, Vol. 4(4), 122-132. 